\title{
Pupils with special educational needs in the context of vocational education in Poland
}

\author{
Maciej Bochyński, Joanna Klimek, \\ Katarzyna Lisowska-Strzępek, Kamila Morzyniec, \\ Mateusz Sawicki, Katarzyna Zielińska
}

\begin{abstract}
The article presents vocational education of pupils with special educational needs in Poland, in the context of current barriers that hinder disabled persons from vocational work fulfilment. Vocational education has been described at all levels of the present system with reference to diverse needs of pupils. The analysis of the GUS [Central Statistical Office] data leads to a conclusion that the level of education of the disabled is not sufficient for them to participate in the open labor market. Thus, the necessity of system improvement and flexibility of vocational offers for disabled persons is particularly emphasised, as the forms and content of presently implemented curricula do not befit the rapidly changing conditions on the job market.
\end{abstract}

Key words: vocational education, pupils with special educational needs, individual and social barriers. 


\title{
Situation of the disabled on the Polish labor market
}

\author{
Poland is among a group of countries which are characterized by a large population \\ of disabled persons ${ }^{1}$, with a concurrently low index of their social activation; it specifi- \\ cally concerns people with intellectual and sensory disability and with mental disor- \\ ders. For many years, we have been observing activities aimed at the creation of the \\ possibility of a comprehensive, based on equality rules attendance in social life - it is \\ worth mentioning that the so called "Polish model of vocational integration" has been \\ introduced for many years, still, the presence of the disabled on the Polish labor market \\ is little in comparison with other European countries, and their social participation in \\ some areas is imperceptible (becoming self-dependent, shared accommodation, etc.). \\ Unfortunately, the efficiency of undertaken measures is not sufficient; there is also de- \\ ficiency in system solutions, which would optimally allow to activate disabled persons \\ in vocational, educational or personal space.
}

1 The phenomenon of disability is larger in Poland than in most countries, even when taking definition differences into account. One of the reasons is the fact that over $1 / 3$ of persons at a working age who are "lawfully" disabled, are not "biologically" handicapped. The age cross-section of persons being "lawfully", but not "biologically" disabled, suggests that the system is being used as a form of early retirement. More than $12 \%$ of all men at the age of $60-64$ and over $11 \%$ of all women aged 55-59 have a certificate of disability, even if they do not feel handicapped themselves. This relatively often occurrence of disability in Poland is also to a large extent a consequence of a lenient system of adjudicating disability before 1999. For this reason, about 1.7 million people (data from the National Census of 2002 and 1.4 million according to the health assessment of 2004) were officially declared disabled, although they did not suffer from physical or mental handicaps. The situation may result from the presently functioning system of disability adjudication. On the other hand, more than 1 milion people, who have a biological handicap, were not officially adjudicated disabled. This phenomenon, however, mainly concerns retired persons in whom disability developed at an older age (cf. Chłoń-Domińczak, A., Poznańska D., 2007, p. 17).

It is worth reminding that there are three independent systems of adjudicating disability in Poland - the first, for disability pension purposes, performed among employees and self-employed persons, the second executed within the social insurance of farmers, and the third - assigned to purposes not related to disability pensions, administered by local authorities.

Considering a high number of applications and eligible persons in the employees system, procedures were reformed in 1997, which led to a decrease in the number of disability pensioners (see: Wóycicka l., Ruzik A., Zalewska H., 2002).

According to the results of a quarterly representative Research of Population Economic Activity (BAEL) carried out by GUS the number of disabled persons aged 15 and over, had been systematically falling down since 2002 and amounted to 3.7 million in 2008. It means that $11.8 \%$ of the population aged 15 and over, have a lawful certificate of disability. In the year 2008 , the number of lawfully disabled persons at the working age was about 2.2 million and accounted for $9.3 \%$ of the population at that age. In $2008,26.9 \%$ of persons aged 15 and over, had a severe degree of disability certification (or equivalent), $38.1 \%$ of those persons had a moderate degree of disability certification (or equivalent) and $35.0 \%$ had a certification of a mild degree of disability (or equivalent). Among handicapped persons at a working age, the percentage of persons with a severe degree of disability is by far lower, with a distinctly higher percentage of persons with mild disability (the percentages are $18.7 \%, 39.8 \%$ and $41.5 \%$ respectively) (source: http://www.stat.gov.pl/bdl/app/ dane_podgrup.hier?p_id=431279\&p_token=1883766014\#) 
The analysis of the social reality of disabled persons inclines to some generalizations:

1. Constant lack of legal stabilization, which causes that the information about new legal acts does not reach the most interested ones, moreover, legal regulations do not ensure complete protection to the disabled, even in area of work access on the open market, legal contradictions as regards entering into marriage of adult disabled persons, etc.

2. Results of the quarterly Research of Population Economic Activity (BAEL) ${ }^{2}$ conducted by GUS show that disabled persons are usually less educated than the able-bodied ones. In 2008, as much as $68.1 \%$ of disabled persons at the age of 15 and over did not have secondary education, and only $6.1 \%$ had higher education. As a matter of fact, this relation is more favourable; however, the difference in that regard is still noticeable in comparison with able-bodied persons, among whom $48.8 \%$ did not possess at least secondary education, whereas $16.5 \%$ had higher education. The disabled encounter difficulties not only in obtaining or completing education at a higher level, but also at the secondary and elementary ones. In turn, low education or the lack of it decrease the chances of the disabled on the labor market, and the chances of life with dignity. The highest vocational activity is featured by persons with higher education.

3. Social and economic situation of particular population groups, including the disabled, is a derivative of their situation on the labor market. The results of the Research of Population Economic Activity (BAEL) ${ }^{3}$ in Poland present a considerable improvement of the situation on the job market in the last three years. There was an increase of the employment indicator and decrease in the rate of unemployment. And, even though the situation of disabled persons is still much worse than that of the able-bodied ones, beneficial changes must be noted. Most of the handicapped working at the age of 15 and over are hired employees $-65.6 \%$ in 2008, but there is also significant percentage of self-employed persons and employers (all $23.6 \%$, including $2.6 \%$ of employers) and helping members of families (10.8\%), which follows from the fact that a substantial part of the disabled work in individual farming. A vast majority of disabled hired workers are employed in sheltered workshops. In December 2008, 39.4 thousand of the disabled working on the open market and 163.3 thousand of working in sheltered workplaces, were registered in the system of servicing financial support led by the State Fund for Rehabilitation of Disabled Persons. Although the domination of sheltered market employment is still significant $(80.6 \%)$, there is a clearly evident rising tendency in the share of employees from the open market (from 15.9\% in December 2005 to 17.9\% in December 2006, and $19.1 \%$ in December 2007 to $19.4 \%$ in December 2008) ${ }^{4}$.

\footnotetext{
2 Source: http://www.stat.gov.pl/bdl/app/dane_podgrup.hier?p_id=431279\&p_token=1883766014\#

3 Source: http://www.stat.gov.pl/bdl/app/dane_podgrup.hier?p_id=431279\&p_token=1883766014\#

${ }_{4}^{4}$ Source: http://www.stat.gov.pl/bdl/app/dane_podgrup.hier?p_id=431279\&p_token=1883766014\#
} 
4. The most difficult situation is that of disabled persons living in the country, not related to farming, though, paradoxically, farming gives employment to many handicapped people, especially to the elder and less educated ones. However, we have noted a decrease in the vocational activity of the disabled connected with farming in the recent years. Most of disabled persons remain out of the job market and this phenomenon has been observed for many years, including people at a working age as well. In $2008,83.9 \%$ of the disabled at the age of 15 and over were vocationally inactive, and $75.7 \%$ of persons at a working age (in comparison with the share of the able-bodied ones $-40.6 \%$ and $25.3 \%$, respectively). Therefore, legislation measures that support the activation of those persons are still being taken.

\section{Vocational discrimination of the disabled}

The problem of vocational discrimination of disabled persons is generally related to barriers that restrain their vocational activity. There are many barriers like that, some lie in the disabled workers, others in employers, many of them reside in the social approach towards disabled persons (A. Barczyński, P. Radecki, 2008: S. Kowalik 2007: A. Ostrowska, J. Sikorska, B. Gąciarz, 2001).

7. Individual qualities of a disabled person may strengthen or weaken the results of disability. The barriers are crucially diversified depending on age, health condition, education, manners, approach to difficult situations, vocational preparation, type of disability, family circumstances, financial situation, intellectual, emotional, physical ability, little vocational mobility of disabled persons.

A significant factor that hinders the disabled from vocational activity is low self-esteem and negative assessment of the possibilities of gaining employment. Disabled persons are also self-discriminating, that is, they discriminate themselves due to the existing disability, which as a result contributes to vocational inactivity (K. Osińska, 1986). Prolonging period of being out of work can lead to the appearance of multiple negative consequences (I. Poliwczak, 2008). Lack of work causes the intensification of ailments connected with the main reason for the body dysfunction; it may also conduce to the emergence of new ones. The relationship between the limited possibilities of finding employment by the disabled and the low level of vocational qualifications and low level of education is emphasized as well. The duration of time without work also impacts finding employment. The longer a disabled person is out of work, the lesser the chances of employment. Intellectually disabled persons are in the worst position. In the case of intellectually disabled persons, the capability of performing vocational work depends on the degree of disability and the employer's willingness to cooperate, as well as on the suitable selection of the type of work to match the employee's individual abilities. The 
issue of the lack of sufficient vocational preparation of intellectually disabled persons, who leave school, is a separate problem.

8. The attitude of an employer to hiring a disabled person may be influenced by additional obligations (necessity to bear higher costs, extended reporting, necessity of technical - organizational changes in the company, requirements regarding the preparation of objects, necessary preparation of workplaces). Employers are also unwilling to take on disabled persons because of a large number of inspections and complicated bureaucracy. The existing system of equalizing the chances of the disabled in Poland is mainly criticized by employers for its low efficiency and efficacy. The system is of a rather compensatory than activation nature, it preserves inactivity - merely $5 \%$ of financial resources are allocated to vocational activity and substantial help, whereas nearly $80 \%$ is used to pay out disability pensions.

9. Barriers of external nature are created by: social policy, employment policy, the condition and efficiency of functioning of pension and disability pension systems, treatment and health rehabilitation, place of residence, legal situation of the disabled in the state, attitudes of the environment, access to education and social welfare, prejudices of colleagues.

Limitations resulting from external surrounding, and being a derivative of the principles of rehabilitation system functioning, are lack of stability of functioning system principles, complex procedures and diverse sources of financial support. Conditions of labor market functioning that impact the low vocational activity of disabled persons are the following: level of services provided to the disabled including vocational counseling, employment agencies and the issue of additional trainings, lack of job offers for the disabled, ill-organized system of vocational education - education in professions that do not guarantee employment (occupations such as: broom-maker, potter, etc.).

Additional problem, being a factor that substantially makes it difficult for the disabled to find employment, is structural unemployment on the Polish job market, connected with ill-adjusted structure of work resources, both in the geographical and qualification - vocational respects. This situation causes disproportions on the labor market. III-adjustment of structures regarding geographical location consist in the fact that the structure of work supply considering the place of residence does not match the demand for it within these sections. Statistically speaking, the worst situation is in villages and small towns, where the rate of unemployment is high. This type of structural mismatch is of crucial importance for those disabled who are significantly limited by their handicap in the search of finding work outside their place of residence, or for whom the search is impossible due to the very same reason. On the other hand, ill-adjustment of the qualification - vocational structure, causes that the employee's vocational qualifications do not match the real demands of the labor market. Disabled persons with low vocational qualifications are exposed to more often losses of employ- 
ment as a result of enterprise reorganization (redundancy). Unfortunately, interesting job offers are aimed at persons who are willing to requalify immediately or relocate, which is difficult in the case of the disabled.

Barriers that make it difficult for the disabled on the employment market must include instability and inefficiency of the Polish system of vocational rehabilitation.

Here, it is also worth referring to an interactive model of vocational rehabilitation of persons with intellectual disability presented by W. Otrębski (2007). This model focused on the issue of vocational interests and vocational competences of intellectually disabled persons. The model assumes that vocational activity of an intellectually disabled person that agrees with their interests is a guarantee of a higher level of vocational competence.

\section{Education of pupils with special educational needs in Poland}

Education of man who is intellectually disabled should be perceived as vocational preparation $^{5}$. According to the proposition of Z. Gajdzica (2001, p. 391) three basic periods are distinguished:

- "vocational preorientation led in elementary classes of primary school,

- vocational orientation carried out in the senior classes of primary school,

- vocational education in vocational schools".

The Polish system of education of children and youth with special educational needs is an integral part of the operative school system in the country. In Poland, a system of partial integration with mainstream education is functioning. For many years, special

\footnotetext{
${ }^{5}$ It is worth presenting interesting results collected from studies done by B. Oszustowicz and J. Baran (1999). The authors carried out an experimental program of vocational orientation in a class at a special school. 30 intellectually disabled pupils took part in experimental classes. The control group also consisted of pupils with intellectual disability, not participating in the project. The experiment involved four stages of activities. In the first, the participants had to fill out two surveys: about the selection of occupation, and school and extraschool interests. The second stage included engaging pupils from the experimental group in the vocational orientation classes. At the third stage - having completed the experimental classes and starting education in a vocational school by pupils - using a survey, information on the aptness and satisfaction from the chosen path of education, and the usefulness of vocational orientation classes, was collected. The last stage - performed a few months after starting education in a vocational school - consisted in completing another survey by the studied group and writing a composition about plans for life, interests and preferred values. It turned out that vocational orientation classes help special school pupils in the preparation for informed selection of occupation, contribute to the formation of a real picture of one's own abilities, prompt motivation to study and work, as well as facilitate the process of adjustment at the next level of education - in vocational school.
} 
education was inseparably connected with the functioning of special school. Nowadays, it is run in other establishments, not only integrative, but also in mainstream ones.

In Polish educational system children and youth with special educational needs may be educated in:

1. special schools,

2. special classes at mainstream schools,

3. in integrative classes at mainstream schools, integrative schools, the so called integrative form (including),

4. in mainstream class through individual education, so called integrative (including) form,

5. through individual education (individual education, most often at the pupil's home).

Special education system in Poland generally reflects the premises and structure of the general one; however, due to the peculiarity of didactic and educational work with pupils with special educational needs, we can talk about its dissimilar components and characteristics (Fig. 1).

\section{Psychological and pedagogical assistance for children and the youth}

The Regulation of $2010^{6}$ sets new rules of providing and organizing psychological-pedagogical assistance in public nursery schools (kindergartens), schools and establishments which allow for providing each student with comprehensive psychological-pedagogical assistance in the environment of his/her education and upbringing. The student should be provided with individualized psychological and pedagogical help in accordance with his/her individual developmental and educational needs and psychophysical capabilities, identified by a teacher or specialist who tutors the student.

This regulation came into force on the first of February 2011 and shall not be effective until the school year 2011/2012.

According to the mentioned regulation, the help given to the student in kindergarten, school and establishment, consists in identification and fulfilment of the student's individual developmental and educational needs, as well as in identification of his/her individual psychophysical capabilities. It defines the recipients of psychological and pedagogical help as people having difficulties that result from differentiated input.

In the effective regulation, classes applying to the selection of educational direction and occupation, as well as education and professional career planning, are defined as

\footnotetext{
${ }^{6}$ Regulation by the Minister of National Education of 17 November 2010 on the rules of organizing and providing psychological and pedagogical assistance in state nursery schools, schools and establishments, Journal of Laws No. item 1487.
} 
Fig. 1: Special education system diagram (based on Sowa \& Wojciechowski, 2003, p. 134).

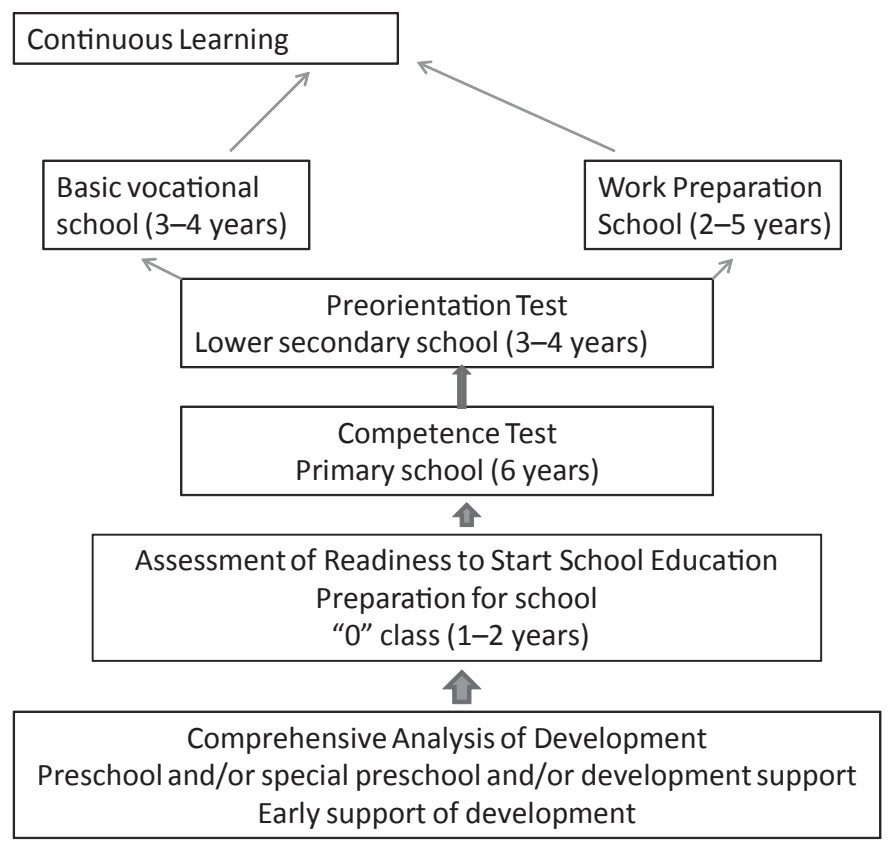

one of the ways of giving psychological and pedagogical support. Classes connected with the selection of educational direction and occupation, as well as education and professional career planning, are organized in order to support the students of lower secondary and upper secondary school in taking educational and vocational decisions using active work methods. These classes are run by teachers, tutors of educational groups and other specialists - including career counsellors. Planning and coordination of psychological and pedagogical assistance distribution is dealt with by a team of teachers, tutors of educational groups, and specialists who have classes with the student.

In theory, the new regulation leads towards the real inclusion, however, in practise the goal is difficult to obtain. 


\section{Vocational education of pupils with special educational needs}

\section{Prevocational education at the preschool level}

Pre-primary education establishments are the establishments that take care and prepare children for school education. Such establishments are designated for children between the age of 3 and the beginning of their education in a primary school. Preprimary education establishments include: nursery schools, pre-primary sections of primary schools, since the school year 2008/2009 they also comprise pre-primary education groups and pre-primary points. Until the school year 2003/2004, a child had the right to a one-year of pre-primary school preparation.

Special nursery schools are organized for children with moderate or severe disabilities - visual, hearing, motor-skills disability, chronic illness (in health care centers), with intellectual disability or multiple disability. A special nursery school can be an independent establishment or can be organizationally related to a special primary school, a special education center or a healthcare facility. Obligatory schooling is postponed in the case of a child who has been diagnosed as needing special education, or a child over the age of 6 who is provided with special pre-primary education, but no longer than to the end of the school year in the calendar year in which the child is 10 years old. In the case of a child who has been diagnosed as needing special education, the obligation of a one-year pre-primary school preparation starts at the beginning of the school year preceding the school year in which the child starts fulfilling obligatory schooling.

A nursery school bases its caring-educational interactions upon "The Core Curriculum for Nursery Education, Nursery Schools, Preschool Departments and Other Forms of Preschool Education" drawn up by the Ministry of National Education and upon the Curricula for preschool education.

The Core Curriculum for Preschool Education 7 describes a comprehensive process of supporting the development and education of nursery schools' pupils. It defines the goals of preschool education and areas of educational interactions. The purpose of preschool education is to support and direct a child's development in accordance with his/her innate potential and developmental abilities in relation to the socio-cultural and natural environment.

Therefore, preschool education is aimed at mastering skills and knowledge that children ought to display when they start school education.

Preschool education curricula contain ways of goal achievement based on the areas presented in the core curriculum. There is no single binding preschool education cur-

\footnotetext{
7 Appendix to the Regulation by the Minister of National Education of 23 December 2008 Journal of Laws of 15 January 2009, No. 4, item 17.
} 
riculum; its choice lies in the hands of a teacher who is in charge of a given group of pupils. The teacher may make use of ready-made curricula, or prepare one on the basis of the core curriculum. It is worth mentioning that the same core curriculum applies to disabled children as well as to the healthy ones. No separate preschool education curricula have been issued for these children either. Thus, teachers who work in a given nursery, must draw it up on their own.

However, individual educational-therapeutic curricula are drawn up for pupils with special educational needs, the curricula allow for the children's needs and abilities ${ }^{8}$. Preschool education curriculum for a given child is adjusted and approved for a particular establishment within these curricula, then appropriate methods, means and forms of implementation are selected. Moreover, according to MEN's recommendations, children with special educational needs have classes in smaller groups; they may take advantage of specialized psychological and pedagogical assistance.

Thus, prevocational preparation of children going to a nursery school is not explicitly formulated in the above mentioned areas of preschool education. Lack of explicit, top-down recommendations, as regards the preparation of disabled children for fulfilling a role of an employee in the adult life at the preschool education stage, causes that the introduction of such content depends on the teacher's invention. The teacher must see his/her pupil in a comprehensive and prospective way, i.e. focus in his/her interactions not only on the present, but also reflect on which skills and knowledge (also the one enabling them to take up work), they will need in the adult life. All actions that teachers take towards their pupils in a nursery school and which focus on inspiring confidence in their own abilities aiming at the most self-reliance, understanding applicable behavior rules in the society and arousing respect for work as a value, may be perceived as prevocational education.

\section{a) Prevocational education at primary school level}

(Stage 1 - Integrated education and Stage 2 - subjective education)

Prevocational education is the first and probably the most fundamental stage of education connected with the individuals' vocational education and their development. In some countries, it is treated as a peculiar connection of theoretical knowledge with the pupils' life experience, in other countries it is seen as linking general education with practical problems of work, whereas in yet another ones, with the process of school and vocational orientation. In Poland, it is understood as a characteristic process of education through work and to work.

\footnotetext{
8 Regulation by the Minister of National Education of 17 November 2010 on the rules of organizing and providing psychological and pedagogical assistance in state nursery schools, schools and establishments, Journal of Laws No. item.
} 
Within the integrated education, which includes the first 3 years of primary school, the content connected with prevocational counselling focuses on the three areas:

1. knowledge and learning about the world and oneself;

2. ability to act in the world;

3. values and attitude towards the world and oneself.

As for the teaching method, nowadays, the authoritarian model of a teacher giving pupils ready-made material is becoming a thing of the past, today, pupils are made to discover the world and search for knowledge on their own. Therefore, it is good when the teacher creates such situations, in which a child is able to recognize his/her own cognitive abilities, strengths and weaknesses. The pupil should be able to communicate, build social relations, and also have knowledge about the natural, cultural and technical environment. During the first years in primary school, pupils should learn how to get to know and manage themselves, act skilfully in the world of various contexts (practical, cognitive and symbolic) and in diverse social groups. In the core curriculum for elementary education, we read that in the scope of relations to themselves and the others, the pupil should acquire the following content:

- development of the sense of self-esteem and self-identity (self-confidence, selfreliance, ethnic, cultural identity, etc.);

- introduction of the child into the spiritual and material culture (one of the family, region, country, Europe and the world);

- spiritual and moral development (shaping beliefs and socially valuable attitudes, e. g. towards the younger, the weaker, the suffering, respect for one's own work and the work of other people, confidence in oneself).

The core curriculum of general education for primary schools assumes that the pupil who finishes the third grade, within social education, understands the importance of work in man's life; knows the occupations of his/her relatives and friends; and is also aware of the occupational specificity, e. g. of a railway man, chemist, police officer, vet.

At the 2 nd stage of education, elements of prevocational education are present in all subjects and on all paths. However, they have a different meaning for this type of learning - some of them (e. g. Polish, Maths, Music, P.E.) focus on the general culture of the individual, which is obviously essential in shaping pupils' attitude towards work. Others (History, Civics) persuade to reflection on oneself and the social environment, on the issue of each man's distinctness and uniqueness, each man's needs and means of meeting them, also, on the importance of work in man's life and its social distribution. However, such subjects as IT or Technical Education are almost entirely planned for prevocational education as pupils gain most practical knowledge in these classes. 
b) Pro-vocational education in lower secondary school and vocational counselling The following are mentioned among the conditions that need to be fulfilled so that the disabled youth was properly prepared for work:

1. Correct qualification for a proper direction of vocational education, in accordance with psychophysical abilities, interests and employment opportunities;

2. Provision of proper organization of the didactic and educational process (appropriately equipped workshops and laboratories, suitably trained teaching staff, the use of the most efficient methods and forms of teaching);

3. Adjustment of curriculum requirements for particular subjects to the cognitive capabilities of the youth.

At the 3rd level of education, completed in lower secondary school and the following 4th level (upper secondary school), which have similar tasks, students obtain education that allows them to acquire vocational competences and then improve them during years of work. The aim of general education at levels 3 and 4 is just enabling and facilitating the selection of educational and vocational paths by providing access to information, guidance and career counselling.

The In-School Vocational Guidance Project at the level of lower secondary school and developed by the National Education Support Center may be an example to follow for the creation of counselling in schools, based both on cooperation with students and their parents. It determines the tasks of the Board of Teachers, allowing for the creation and maintenance of the in-school counselling system's uninterrupted activity in compliance with the school charter, definition of priorities regarding vocational knowledge and information within the school educational curriculum for each year of learning, as well as the fulfilment of activities in the scope of students' preparation for career path selection, included in the school educational curriculum. It assumes that in the first year of learning in lower secondary school, students will be stimulated to get to know one another, in the second one, they will have a chance of getting acquainted with particular occupations and make a preliminary decision, whereas in the last year they will gain educational and vocational information that will allow them to confront self-evaluation with the demands of schools and occupations, which will enable them to take a final decision. As early as from the 2 nd grade, pressure must be put on students who show problems with school and occupation selection which is supposed to be leveled by the intensification of individual work.

Cooperation with parents ought to run at 3 stages. The first one should include getting parents acquainted with the school informative and counseling activities and organization of psycho-educational classes which enable to support the child in making educational and vocational decisions, the next one is involving parents as representatives of various professions into the course of informative activities carried out by the school, and finally, making it possible for parents to get acquainted with the full offer 
of secondary education, and also, individual work with parents of students who show health, emotional, decision-making, intellectual, family and other problems, as well as cooperation with pedagogical and psychological counseling center.

Since 1 September 2009, a stage of changes has begun, changes meant to implement the new core curriculum which imposes on educational establishments a responsibility of a very individual approach towards each student, in order to meet their needs, difficulties and interests, and which is to bring about an increase in education effectiveness, especially for people with special educational needs. These changes assume the achievement of the set goals due to the cooperation of the teacher, pedagogical and psychological assistance and the parents through individual work with the student (Ministry of National Education, 2010). This system, defined as the in-school system of vocational guidance also imposes a responsibility of "tutoring in the selection of educational direction, as well as organizing interactions with psychological-pedagogical counseling centers, including specialist counseling service, and between other institutions that provide guidance and specialist help services to students and parents ${ }^{\prime \prime}$. Work with the student ought to take place on the basis of Individual Educational-Therapeutic Schemes which should adapt the core curriculum to the disabled student's capabilities, but it also accounts for therapeutic functions based upon building a positive relation with the student and supporting his/her social development through various forms of rehabilitation interactions. The Individual Scheme expresses the school's activities adjustment to the psychophysical needs of a particular child, hence it should account for the information from all specialists who work with the child and from the parents, it ought to be "an author's plan including learning content, methods and forms of work in particular, or in all subjects or educational areas" (Ministry of National Education, 2010).

It has been postulated to employ career counselors, who will deal with the coordination of activities within the In-School Systems of Vocational Guidance ${ }^{10}$, in all lower secondary schools. Their purpose should not only involve making it possible for students to learn about jobs offered by the labor market, but also learning about requirements that need to be met when applying for a certain post and, most of all, the development of awareness concerning one's own talents, qualifications and interests. Their task includes, in particular: assistance with education and career planning, gathering, updating and making educational and vocational information available, showing students, parents and teacher additional sources of information, giving students and parents individual advice, running group activation classes, preparing students for conscious career planning and taking up a vocational role, supporting students and teachers in guidance activities, cooperating with the board of teachers in the scope of

9 Regulation of the Minister of National Education and Sport of 12 February 2002 on the framework curricula in public schools, Journal of Laws of 2002 No. 15, item 142.

10 Regulation by the Minister of National Education of 17 November 2010 on the rules of organizing and providing psychological and pedagogical assistance in state nursery schools, schools and establishments, Journal of Laws No. 228, item 1487. 
ensuring uninterrupted activities of the in-school guidance system and cooperating with institutions that support this system.

\section{c) Vocational education at post-compulsory level}

The aim of vocational education is preparing those in education for life under the conditions of contemporary world, for working and active functioning within the changing labor market.

The task of school and other entities that run vocational education and the way of their completion are conditioned by changes in the economic and social environment, particularly impacted by: the idea of economy based on knowledge, economic and social processes globalization, growing share of international trade, geographical and vocational mobility, new techniques and technologies and the growth of employers' expectations in the area of employees' knowledge and skills level.

Vocational education is implemented in secondary schools: basic vocational school, secondary technical school and post-secondary school. Students fulfil the curriculum act that is modified depending on the individual limitations of a student. General vocational education - broadens the range of knowledge and skills in accordance with the student's interests and talents, leading to professional work. Learning in a basic vocational school prepares the student for taking up a job on the basis of the certificate that confirms his/her professional qualifications.

In schools that are not of vocational character, according to the regulation by MEN of 21 March $2001^{11}$, the so called internal guidance system was created, through which students may gain support in the recognition of their own competences, skills and vocational predispositions.

The selection of occupation is important for every man; however, it is a particularly crucial life decision for people with SEN. As a rule, they encounter more problems with the optimal choice of occupation than the healthy ones. People with SEN usually have, though in a diverse scope and degree, a limited work capacity due to lowered functional ability of the body, which causes that it is more difficult for them to evaluate their occupational abilities and position on the labor market on their own. Taking wrong or random vocational decision entails much more serious consequences for people with SEN than for the healthy ones. Since they are exposed to needless effort connected with obtaining professional qualifications, which is not fruitful as regards the chance of taking up a job. As a result, the disappointment and stress caused by it may lead to giving up further vocational rehabilitation and vocational activity. It is worth pointing out the fact whether the student is aware of his/her health condition, or is able to demonstrate his/her own advantages, or rather has a tendency to deprecate himself/

11 Regulation of Minister of National Education of 21 March 2001 on the conditions and method of assessing, classifying and promoting pupils and students, and conducting examinations and tests in public schools. 
herself and that the technological progress and future occupations, may change the existing contraindication to performing particular jobs. Whether the student is able to keep distance to his/her, sometimes unreal, ideas of future vocational goals. The general rule when selecting an occupation is to match the kind of job to the psychophysical condition of the candidate. It would be ideal if the selected occupation (activity, kind of work) agreed with his/her interests and intellectual abilities. It is worth emphasizing that the final decision regarding future planning is up to the student and his/her parents. Moreover, it must be remembered that as regards methodological and education completion/work performance contraindications, solely the so called industrial medicine doctors, not career counselors, are authorized to adjudicate. It must be kept in mind that the student with special educational needs is also a talented one. The work of a career counselor with the talented student may consist in developing interests and work motivation, shaping creative thinking, shaping personality in the area of work, supporting personal development, developing the student's talents as a source of vocational competences. Systematic and continuous work of career counselors/vocational teachers-guides with students, including those with special educational needs, leads to the creation of a coherent labor market. Thanks to the creation of new chances of all students' vocational development, their potential, which is knowledge and skills, will be better used. It is particularly important from the point of the modern labor market and economy based on knowledge.

Vocational education at special vocational schools proceeds according to a set school profile. Both in Poland and in other European countries, a cycle of broad-profile ending with a specialization module, is used in vocational education. Broad-profile profession enables a wide area of employment, creating the basis for multi-direction specialization in the course of vocational work, and allows retraining and gaining additional professions.

Vocational education is mostly offered at two levels: the level of special and basic vocational schools, whose graduates get the title of a qualified worker or an apprentice in some occupations, and the level of special vocational secondary technical schools, the completion of which provides professional qualifications at the secondary level (a technician) (Otrębski, 2007). Those schools' graduates are prepared for the open labor market and supported employment.

1. Special vocational and basic vocational schools are adjusted (in terms of curriculum and organization) to the needs and intellectual-physical capabilities of youths with disabilities. Special vocational and basic vocational secondary schools can be organized as independent institutions, or as integral parts of other educational institutions. They can also be set up in healthcare institutions. The student is able to achieve a diploma certifying his/her professional skills. These schools are meant for the youth with mild and moderate level of intellectual disability and are designed to provide special circumstances of work preparation and achieving professional 
qualifications. They are open to graduates of special lower secondary schools for the youth aged $16-18$ (in some cases even for 21 or 24 year-olds). Depending on the type of school, the course of study lasts from 2 to 5 years and comprises two stages of different curriculum, as well as contact with vocational practice: general social and vocational training (1 or 2 years) and profiled vocational training (2-3 years).

- Work preparation schools are intended for students with moderate or severe intellectual disability and for students with multiple disorders with the option of extension up to the age of 24. A graduate from a work preparation school receives a school-completion and job-training certificate. No further schooling is anticipated after completion of such a school. Learning in such schools should prepare the student to carry out the activity of working within the sheltered (supported) employment (sheltered workshops, occupational workshops, occupational therapy workshops)

- Training and rehabilitation centers are mainly meant for people with physical disability. They fulfil the task of social and vocational rehabilitation through the following activities: organization and maintenance of social infrastructure providing accommodation and catering for participants of such trainings; the organization and maintenance of didactic infrastructure; organization of diagnostic tools making it possible to carry out comprehensive evaluation of psychological and physical abilities in the aspect of professional opportunities; providing proper staff and conditions to conduct social and treatment rehabilitation with special emphasis on the degree and type of disability.

Practical classes and training periods are important components of vocational education. The quality of practical education is largely determined by didactic facilities. Practical education may be carried out:

- in practical classes labs,

- in school workshops,

- in Centers for Practical Education,

- in Centers for Continued Education,

- at the employer's.

Professional development of the disabled includes almost their entire lives and leads to obtaining qualified professional work. The employment took up by graduates boils down to two forms (Majewski, 1995): employment in the open labor market and employment under special conditions. A disabled person can accept employment on competitive terms. In regular production plants, service industry, agriculture and institutions, they may be employed on the same terms and work in the same conditions as able-bodied workers. The only privileges that a disabled person has in this case follow from the general regulations of their employment, i.e. shorter work time, longer leaves, doing the job only during the day, adjustment of work station. 
The disabled may also work under proper conditions with the help of a professional assistant or a supporting investor (Mikulski, 1994). Proponents of this form of employment emphasize that it is relatively less costly and fulfils such a crucial, in recent times, condition of social integration. It is also possible to set up one's own business or agricultural activity. Having a business or running agricultural activity is a chance for work, mainly for the disabled who live in areas with a very high rate of unemployment, or in small localities where chances of finding a job are little. However, this type of employment requires from the disabled person many additional, both vocational and soft skills.

\section{Conclusions}

The reform of education serves the facilitation of education procedures for the youth with special educational skills, in order to guarantee them better access to employment in adult life. Vocational work is a primary developmental task and right of a human being, as well as the source of quality of life, thus, the state ought to make efforts, and through proper legal regulations, favor and facilitate the professional career of the disabled, the preparation for which starts at the stage of preschool education and is continued throughout the whole life.

\section{References}

Badania Aktywności Ekonomicznej Ludności (BAEL): http://www.stat.gov.pl/bdl/app/strona.htmI?p_name=indeks (access 25.06. 2012).

Badania Aktywności Ekonomicznej Ludności (BAEL): http://www.stat.gov.pl/bdl/app/dane_podgrup.hier?p_id=431279\&p_token=1883766014\# (Access 25. 06. 2012).

Barczyński, A. \& Radecki, P. (2008). Identyfikacja przyczyn niskiej aktywności zawodowej osób niepełnosprawnych: raport z badań przeprowadzonych w ramach realizacji Partnerskiego Projektu "Kluczowa rola gminy w aktywizacji zawodowej osób niepełnosprawnych". Warszawa: Krajowa Izba Gospodarczo-Rehabilitacyjna.

Chłoń-Domińczak, A. \& Poznańska, D. (2007). Promocja zatrudnienia niepełnosprawnych na rynku pracy. Budapeszt: Wyd. Międzynarodowej Organizacji Pracy.

Gajdzica Z. (2001). Wpływ treści kształcenia na wybór zawodu przez uczniów lekko upośledzonych umysłowo. In R. Kwiecińska, M. J. Szymański (Eds.), Młodzież a dorośli. Napięcia między socjalizacją a wychowaniem. Kraków: Instytut Nauk o Wychowaniu Akademii Pedagogicznej w Krakowie, s. 390-401.

Kowalik, S. (2007). Psychologia Rehabilitacji. Warszawa: WaiP.

Majewski, T. (1995). Rehabilitacja zawodowa i zatrudnienie. Warszawa: Centrum Badawczo-Rehabilitacyjne Osób Niepelnosprawnych.

Mikulski, J. (1994). Sposoby realizacji systemu rehabilitacji zawodowej i zatrudnienia, Warszawa Centrum Badawczo-Rozwojowe Spółdzielczości Inwalidów.

Narodowy Spis Powszechny z 2002 http://www.stat.gov.pl/gus/8185_PLK_HTML.htm (access 30. 06. 2012). 
Sowa, J., Wojciechowski, F. (2003). Rehabilitacja edukacyjna w zarysie. Ujęcie systemowe. Zamość.

Osińska K. (1986). O społecznym dyskryminowaniu osób niepełnosprawnych. In A. Hulek. (Ed.) Człowiek niepełnosprawny w społeczeństwie. Warszawa: PZWL.

Ostrowska A., Sikorska, J. \& Gąciarz, B. (2001). Osoby niepełnosprawne w Polsce w latach dziewięddziesiątych. Warszawa: ISP.

Oszustowicz, B. \& Baran, J. (1999). Orientacja zawodowa młodzieży upośledzonej umysłowo w stopniu lekkim - uwarunkowania i konsekwencje. In J. Pilecki \& S. Olszewski (Eds.) Wspomaganie rozwoju osób niepełnosprawnych. Kraków: Oficyna Wydawnicza TEXT, pp. 195-202.

Otrębski, W. (2007). Interakcyjny model rehabilitacji zawodowej osób z upośledzeniem umysłowym. Lublin: Wydawnictwo KUL.

Poliwczak, I. (2008). Praca w życiu osób niepełnosprawnych. Znaczenie oraz powody i negatywne aspekty pozostawania bez pracy. In L. Frąckiewicz (Ed.) Przeciw wykluczeniu społecznemu osób niepełnosprawnych. Warszawa: IPSS.

Wóycicka I., Ruzik A. \& Zalewska, H. (2002). Disability Pension in Poland. In Reforming Worker Protections: Disability Pensions in Transition, ILO, Budapest: Central and Eastern European Team.

\section{Contact:}

Maciej Bochyński, Joanna Klimek,

Katarzyna Lisowska-Strzępek, Kamila Morzyniec,

Mateusz Sawicki, Katarzyna Zielińska

National Society for Autism Krakow Branch

Grottgera St.3

30-035 Kraków, Poland

E-mail: biuro@kta.krakow.pl 